\title{
$\mathrm{pH}$, duty cycle, 교반, 첨가제가 $\mathrm{Ni}-\mathrm{TiO}_{2}$ 전기도금 복합체의 $\mathrm{TiO}_{2}$ 공석특성과 열적안정성에 미치는 영향 연구
}

\author{
김명진 ${ }^{\mathrm{a}, \mathrm{b*}}$, 김정수 ${ }^{\mathrm{a}}$, 김동진 $^{\mathrm{a}}$, 김홍표 $^{\mathrm{a}}$, 황성식 $^{\mathrm{a}}$
}

${ }^{a}$ 한국원자력연구원 원자력재료기술개발부, ${ }^{\mathrm{b}}$ 과학기술연합대학원대학교 양자에너지화학공학과

\section{A Study of $\mathrm{pH}$, Duty Cycle, Agitation on the Property of Co-deposited $\mathrm{TiO}_{2}$ and Thermal Stability in the Electrodeposited $\mathrm{Ni}-\mathrm{TiO}_{2}$ Composite}

\author{
Myong-Jin Kim ${ }^{\mathrm{a}, \mathrm{b} *}$, Joung Soo Kimª, Dong-Jin Kimª, Hong Pyo Kimª, \\ Seong Sik Hwang ${ }^{a}$
}

${ }^{a}$ Nuclear Materials Research Division, Korea Atomic Energy Research Institute, Daejeon, Korea ${ }^{b}$ Dept. of Quantum Energy Chemical Engineering, University of Science \& Technology, Daejeon, Korea

(Received March 27, 2012 ; revised June 20, 2012 ; accepted June 28, 2012)

\begin{abstract}
The effects of $\mathrm{pH}$, types of applied current, agitation method and time, additive on the amount of codeposited $\mathrm{TiO}_{2}$ particles in the matrix were investigated. The deposition rates increased with increasing $\mathrm{pH}$ values, while the volume fraction of $\mathrm{TiO}_{2}$ particles and the size of agglomerated $\mathrm{TiO}_{2}$ particles in the composite decreased. The volume fraction of $\mathrm{TiO}_{2}$ particles in the composite decreased when pulsed current of $50 \%$ duty cycle was used. And the size of agglomerated $\mathrm{TiO}_{2}$ particles in the nickel matrix of pulsed current was smaller than that of $\mathrm{DC}$ current specimen. The volume fraction of $\mathrm{TiO}_{2}$ particles in the matrix decreased with longer time by air agitation, but in case of using magnetic bar, volume fraction in the same range of time was relatively constant. The volume fraction of the electrodeposited $\mathrm{Ni}^{-\mathrm{TiO}_{2}}$ composite in the solution containing $0.01 \mathrm{M}$ Dimethylamine borane (DMAB) increased slightly with increasing agitation time regardless of agitation methods. Thermal stability of the electrodeposited $\mathrm{Ni}_{-} \mathrm{TiO}_{2}$ composite increased with lower $\mathrm{pH}$ at the temperature range of $200 \sim 800^{\circ} \mathrm{C}$, and the results showed that the amount of co-deposited $\mathrm{TiO}_{2}$ relies more on the deposition rate than zetapotential of $\mathrm{TiO}_{2}$ particles.
\end{abstract}

Keywords: Electrodeposition $\mathrm{Ni}_{-} \mathrm{TiO}_{2}$, Agitation method and time, DMAB, Thermal stability

\section{1. 서 론}

금속에 산화물 등의 불용성 입자를 분산시켜 만 드는 금속-산화물 분산 복합체는 우수한 기계적 성 질, 부식저항성, 열적안정성, 내마모성 등의 특성을 가져 많은 연구가 이루어져 왔다 ${ }^{1-8)}$. 이러한 금속산화물 분산 복합체는 고온에서 금속을 녹이고, 융 점이 높아 녹지 않는 산화물 입자들을 분산시킨 후 에 온도를 낮춰 만드는 기계적 섞음법(mechanical

*Corresponding author. E-mail : mjkim@kaeri.re.kr mixing), 금속입자를 분산시킨 후에 고온에서 열처 리 하여 만드는 내부 산화법(internal oxidation) 등 의 전통적인 방법 이외에, 도금용액에 산화물을 분 산시킨 후, 전류를 인가하여 만드는 전기도금법이 이용되고 있다. 전기도금법은 고온이 아닌 상온에 서 진행되고, 간편하며, 경제적인 방법으로 제조할 수 있어, 많은 연구자들이 관심을 가지고 개발 중 이다. 전기도금법으로 제조 가능한 금속-산화물 복 합체는 이론상 거의 제한이 없으며, $\mathrm{Ni}-\mathrm{Al}_{2} \mathrm{O}_{3}{ }^{9)}, \mathrm{Co}-$ $\mathrm{Al}_{2} \mathrm{O}_{3}{ }^{10)}, \mathrm{Cu}-\mathrm{SiC}^{11)}, \mathrm{Ni}-\mathrm{ZrO}_{2}{ }^{12)}, \mathrm{Ni}-\mathrm{TiO}_{2}{ }^{13)}$ 등의 여러 조합이 연구되고 있다. 산화물 등의 불용성 입자들 
이 금속에 공석되는 기구는 아직 명확하게 밝혀지 지 않았다. 이로 인해, 금속 내에 불용성 입자들의 공석량을 예측하기 어려우며, 많은 연구자들이 여 러 도금 인자들에 대해 연구했으나, 같은 인자에 대 해서도 상반된 결과들이 발표되어 공석기구에 대한 혼란이 있는 상황이다 ${ }^{14-20)}$.

본 연구에서는 여러 가지 도금 변수들 중에 $\mathrm{pH}$, 전류 인가 방식, 교반 방식과 시간 등이 $\mathrm{Ni}-\mathrm{TiO}_{2}$ 도 금층에 미치는 영향을 조사하였고, 분산제로서 DMAB(Dimethylamine Borane)를 도금 용액에 첨가 했을 때 나타나는 변화를 연구하였다. 또한 이 연 구 결과로부터 니켈 전기 도금에서 $\mathrm{TiO}_{2}$ 입자들의 공석 기구에 대하여 논의하였다.

\section{2. 실험 방법}

도금용액은 니켈 설파메이트 욕을 사용하였으며, 용액의 조성을 표 1 에 나타내었다. 용액의 온도는 $60 \pm 1^{\circ} \mathrm{C}$ 로 유지시켰고, $\mathrm{TiO}_{2}$ (Aldrich, anatase, $<25 \mathrm{~nm}$ ) 는 $16 \mathrm{~g} / /$ 의 농도로 투입하였다. 전류밀도는 직류의 경우 $100 \mathrm{~mA} / \mathrm{cm}^{2}$, pulse의 경우에는 duty cycle (=(on time) $\times 100 /($ on time + off time $)) 50 \%$ 와 평균 전류밀도 $100 \mathrm{~mA} / \mathrm{cm}^{2}$ 로 인가하였다. 음극과 양극은 판재모양의 $3 \times 5 \mathrm{~cm}^{2}$ 넓이를 가지는 $\mathrm{SS} 304,3 \times 7 \mathrm{~cm}^{2}$ 넓이의 순수니켈을 각각 사용하였고, 음극의 경우 에 뒷면을 절연시켜 한쪽 면만 도금이 되도록 하였 다. 도금 용액의 $\mathrm{pH}$ 는 조절하지 않은 경우에 3.4 였 고, $\mathrm{pH} \mathrm{1,2로} \mathrm{조절했을} \mathrm{경우에는} \mathrm{아미도황산}$ (amidosulfuric acid)을 이용하여 조절하였다. 교반은 공기교반과 자석교반 2가지 방식으로 하였고, 공기 교반 속도는 $0.5 \mathrm{l} / \mathrm{min}$ 이하로, 자석교반의 경우에는 $300 \mathrm{rpm}$ 으로 고정하여 교반하였으며, 교반 시간은 $\mathrm{TiO}_{2}$ 를 투입하고 30 분, 24 시간, 48시간으로 하였다. 제조된 $\mathrm{Ni}_{-} \mathrm{TiO}_{2}$ 복합체의 열적안정성을 조사하기 위해 열처리를 하지 않은 시편과 $200,400,600$, $800^{\circ} \mathrm{C}$ 에서 각각 2 시간씩 열처리를 하여 만든 시편 의 경도를 측정하여 비교하였다. 경도는 비커스 경 도기(HM-124, Akashi)를 이용하여, $50 \mathrm{~g}$ 하중에 10초 측정을 10 회 한 후, 평균을 구하였다. 제조된 시편 의 부피분율은 시편의 단면을 절단하고, 연마한 뒤

Table 1. Nickel sulfamate bath composition

\begin{tabular}{|l|c|}
\hline $\begin{array}{l}\text { Nickel sulfamate tetra hydrate, } \mathrm{Ni}\left(\mathrm{SO}_{3} \mathrm{NH}_{2}\right)_{2} \cdot \\
4 \mathrm{H}_{2} \mathrm{O}\end{array}$ & $1.39 \mathrm{~mol} / l$ \\
\hline Boric acid, $\mathrm{H}_{3} \mathrm{BO}_{3}$ & $0.65 \mathrm{~mol} / l$ \\
\hline Dimethylamine Borane, $\mathrm{C}_{2} \mathrm{H}_{6} \mathrm{BN}$ & $0.01 \mathrm{~mol} / l$ \\
\hline $\mathrm{TiO}_{2}$ (anatase, $\left.<25 \mathrm{~nm}\right)$ & $16 \mathrm{~g} / l$ \\
\hline
\end{tabular}

에 주사전자현미경(Scanning Electron Microscope, SEM, JEOL-6240)의 backscattering으로 시편당 5곳 을 관찰하여 얻은 사진을 이미지 분석기(IMT-2000) 를 이용하여 ASTM E1245에 의거하여 측정하였다. 또한, 이미지 분석기로 얻은 데이터는 미니탭 (Minitab)을 이용하여 통계적으로 $\mathrm{Ni}^{-\mathrm{TiO}_{2}}$ 복합체에 함유된 산화물의 평균 응집 크기와 개수를 구하였다.

\section{3. 실험결과 및 고찰}

\section{$3.1 \mathrm{pH}$ 에 따른 도금 전류효율과 도금층 내 $\mathrm{TiO}_{2}$ 부피분율}

$\mathrm{TiO}_{2}$ 입자는 수용액에서 등전점(Point of Zero Charge, $\mathrm{PZC})$ 이 5 6 사이에 형성되고 ${ }^{21)}$, 등전점을
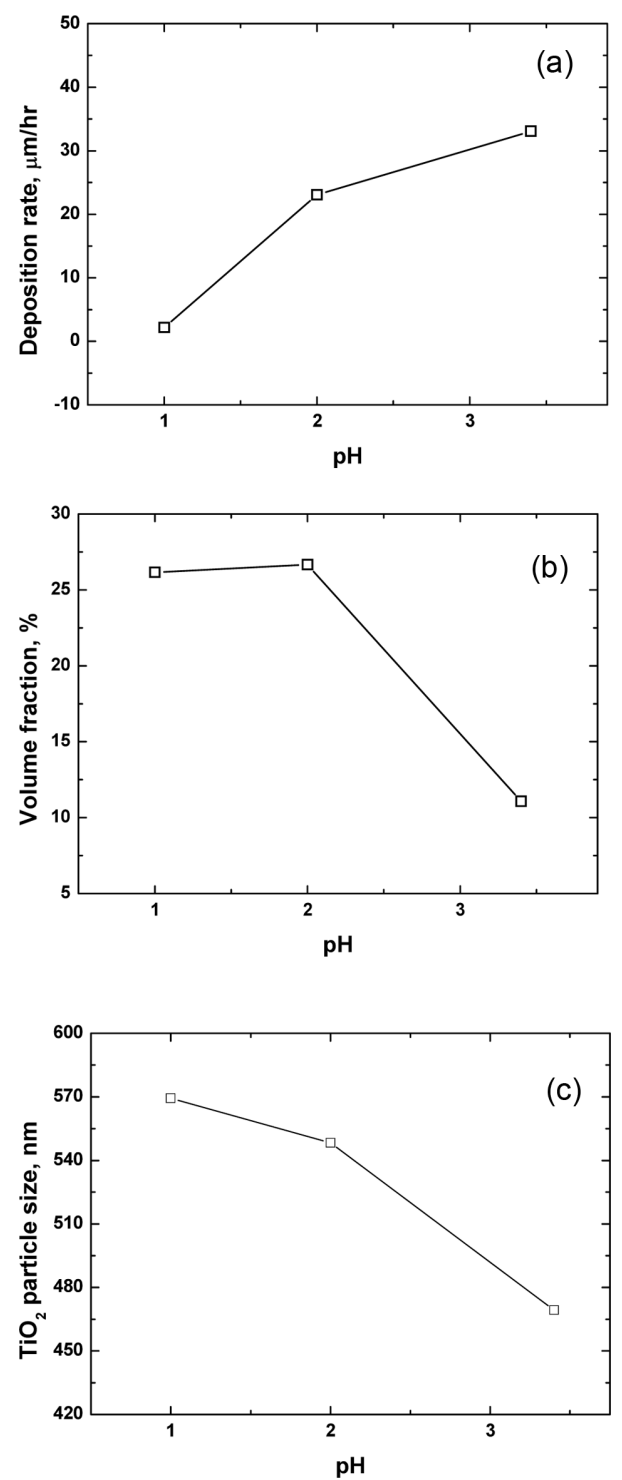

Fig. 1. Electrodeposited $\mathrm{Ni}-\mathrm{TiO}_{2}$ composite as a function of $\mathrm{pH}$ values. (a) Deposition rate (b) Volume fraction of $\mathrm{TiO}_{2}$ particles (c) Mean size of agglomerated co-deposited $\mathrm{TiO}_{2}$ particles. 
중심으로 $\mathrm{pH}$ 가 낮아지거나 높아질수록 제타포텐셜 이 커져 분산 안정성이 증가된다라. 이에 고내마모 성을 얻기 위할 목적으로 도금층 내의 $\mathrm{TiO}_{2}$ 공석량 을 증가시키기 위해 $\mathrm{pH}$ 를 1 3.4 범위에서 변화시 켜 $\mathrm{Ni}-\mathrm{TiO}_{2}$ 복합도금층의 도금속도와 도금층 내에 존재하는 $\mathrm{TiO}_{2}$ 의 부피분율 및 공석된 입자의 평균 응집 크기를 측정하여 그림 1 에 나타내었다. 이 그 림에서 보면 $\mathrm{pH}$ 가 증가하면 도금속도는 증가하는 반면, 도금층 내의 $\mathrm{TiO}_{2}$ 부피분율은 감소하고 있다. $\mathrm{pH}$ 가 증가할 때, 도금속도가 증가하는 것은 도금용 액에서 주 반응인 니켈 이온의 환원 반응과 경쟁하 는 수소이온 농도가 감소하여 상대적으로 니켈 이 온의 환원 속도가 증가하기 때문이다. 한편, $\mathrm{pH}$ 가 증가할 때, 니켈 도금층 내에 함유된 $\mathrm{TiO}_{2}$ 입자의 함량이 감소하는 이유는 크게 2 가지로 생각해 볼 수 있는데, 하나는 $\mathrm{pH}$ 가 증가할수록 수소 이온 감 소로 인한 니켈 도금 속도가 증가하는데, 비전도성 인 $\mathrm{TiO}_{2}$ 입자는 그에 대한 영향이 없어 이동속도가 거의 일정하기 때문이다 ${ }^{23)}$. 또 다른 하나는 $\mathrm{pH}$ 에 따른 $\mathrm{TiO}_{2}$ 입자들의 제타포텐셜 변화를 들 수 있 다 ${ }^{21)}$. 만약 $\mathrm{pH}$ 가 높아질수록 $\mathrm{TiO}_{2}$ 입자들의 제타포 텐셜이 양의 방향으로 감소하여, $\mathrm{TiO}_{2}$ 입자의 전기 영동에 의한 이동도가 작아지고, 그에 따라 음극에 도달하는 $\mathrm{TiO}_{2}$ 입자의 공급량이 줄어든다면 니켈 도금층 내의 $\mathrm{TiO}_{2}$ 함량이 감소할 것이다. 이것은 $\mathrm{TiO}_{2}$ 입자가 수용액 내에서 양의 전하로 수화 (hydrated)되었을 경우인데, 이것을 확인하기 위하여 $\mathrm{TiO}_{2}$ 입자의 제타포텐셜 측정을 시도하였으나 일관 된 결과를 얻지 못하여 확인할 수가 없었다. 하지 만, 다음절에서 나타난 실험결과에서 보듯이, 동일 한 $\mathrm{pH}$ 에서 도금한 경우에도 도금속도와 니켈 도금 층에 함유된 $\mathrm{TiO}_{2}$ 의 양이 서로 반비례하는 것으로 나타난 것을 볼 때, $\mathrm{pH}$ 증가에 따른 $\mathrm{TiO}_{2}$ 함유량 감소는 단순히 니켈 도금속도의 증가에 의한 것으 로 생각된다. 즉, 제타포텐셜과는 무관한 것으로 사 료된다. 이러한 주장은 기존의 연구결과에서도 나 타났는데, White et al. ${ }^{16)}$ 은 1978 년 $\mathrm{Cu}-\mathrm{Al}_{2} \mathrm{O}_{3}$ 계에 서 $\mathrm{pH}$ 0.5 2.6 범위로 실험하여, $\mathrm{pH}$ 가 산화물 자체 에는 영향을 미치지 않고, 금속 환원에 대해서만 영 향을 미친다고 하였고, Tomaszewski et al. ${ }^{3)}$, Chen et $a l^{4)}$, M. Verelst et $a l^{5)}$ 등도 $\mathrm{pH}$ 와 전기도금층 내의 불용성 입자들의 공석량 증감과는 관련이 없 다고 보고하였다. 반면, Fawzy et $a l^{23)}$ 은 $\mathrm{Cu}-\mathrm{Ni}$ $\mathrm{Al}_{2} \mathrm{O}_{3} / \mathrm{TiO}_{2}$ 계에서 $\mathrm{pH}$ 2.5 4.05 구간으로 실험하 여, $\mathrm{pH}$ 가 증가하면, 산화물 공석량도 같이 증가한 다고 보고하였다. 이는 산화물 입자들이 음극에 흡 착할 때, 수소 이온의 감소로 인한 니켈 이온의
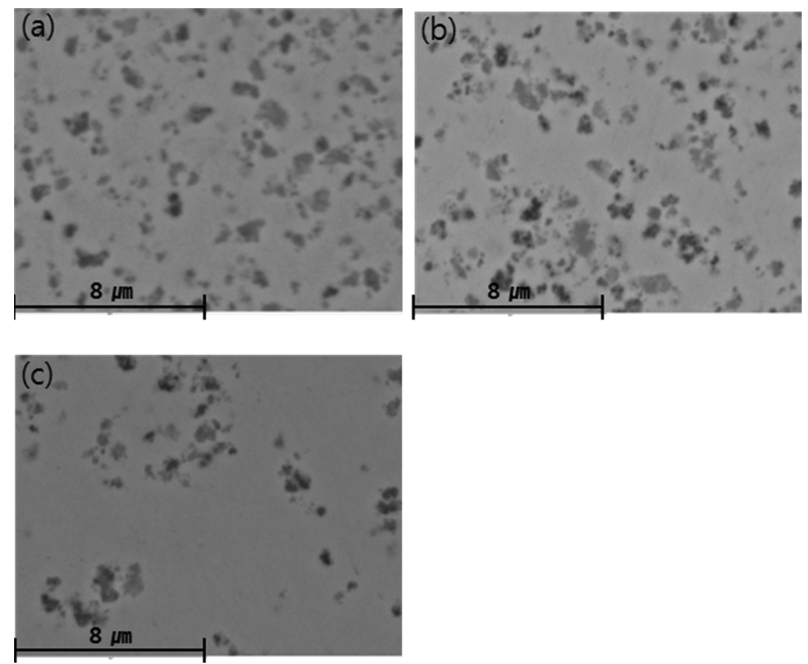

Fig. 2. Cross-sectional images of electrodeposited Ni$\mathrm{TiO}_{2}$ composite with $\mathrm{pH}$ values. (a) 1.0 (b) 2.0 (c) 3.4

specific 흡착이 늘어난 결과로 풀이하였다. Foster et $a l^{24)}$ 의 연구에서는 전류가 인가될 때, 전극과 산 화물 사이에 정전기적 인력에 의한 상호작용이 있 으며, 전기이중층을 통과하면서 산화물 주위의 흡 착 입자들은 제거가 되므로, 입자 주변의 흡착 상 태보다는 산화물과 전극 사이의 상호작용 세기가 더 중요하다고 하였다. 그러나, 도금층 내의 산화물 공석량은 이중층 부근에 분포되어 있는 산화물의 농도와 관계가 있을 것이고, 이중층 부근의 산화물 농도는 분명히 산화물 주위의 흡착물, 즉 산화물의 제타포텐셜에 의존하게 된다. 다시 말하면, 도금층 에 공석되는 산화물양은 전극과 수화된 산화물 사 이의 정전기적 상호작용에 의존하게 되는데, 이것 은 본 연구에서 관찰한 내용과는 상반된 결과를 가 져오는 것으로 본 연구에서 관찰한 결과에서는 정 전기적 상호작용이 크게 영향을 미치지 못하는 것 으로 나타났다. 한편 그림 1(c)에 나타낸 것처럼 니 켈 도금층 내에 공석된 $\mathrm{TiO}_{2}$ 입자 크기도 용액의 $\mathrm{pH}$ 가 증가함에 따라 감소하는데, 이것은 공석량 감 소에 따른 입자 간의 간격이 넓어져 입자간에 겹쳐 상호 엉기는 확률이 감소하기 때문에 나타나는 현 상으로 생각된다. 그림 2 는 $\mathrm{pH}$ 에 따른 도금층의 절 단면을 SEM의 backscattering 방법으로 관찰한 이 미지로서, $\mathrm{pH}$ 가 증가하면 도금층에 존재하는 $\mathrm{TiO}_{2}$ 의 공석량이 감소하는 것을 보여주고 있다.

\section{2 전류 인가 방식에 대한 영향}

표 1 과 동일한 농도의 도금용액으로 $\mathrm{pH}=1.0$, duty cycle $=50 \%$, 평균 전류밀도 $=100 \mathrm{~mA} / \mathrm{cm}^{2}$ 의 펄스 조건으로 제조한 시편과 직류로 $100 \mathrm{~mA} / \mathrm{cm}^{2}$ 

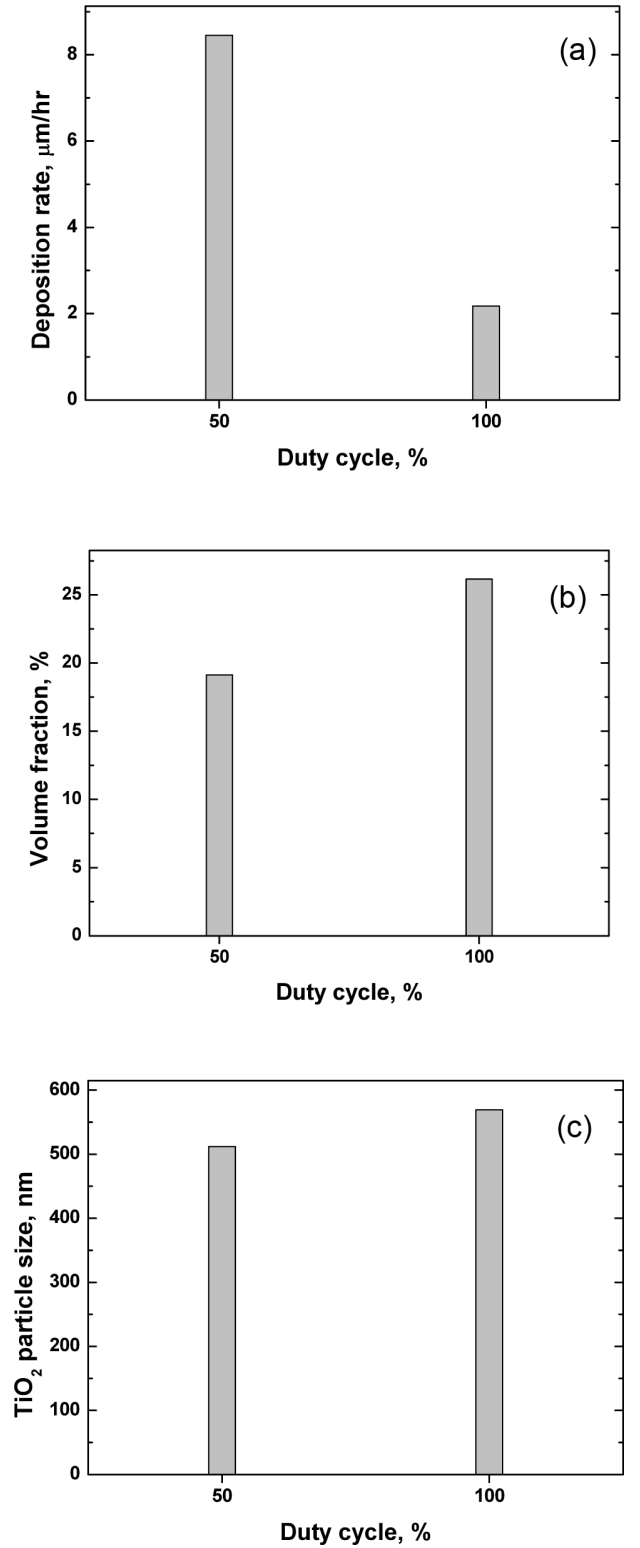

Fig. 3. Electrodeposited $\mathrm{Ni}-\mathrm{TiO}_{2}$ composite with different current characteristics in the electroplating solution of $\mathrm{pH}$ 1. (a) Deposition rate (b) Volume fraction of $\mathrm{TiO}_{2}$ particles (c) Mean size of agglomerated co-deposited $\mathrm{TiO}_{2}$ particles.

의 전류밀도를 인가하여 만든 시편의 도금속도, 도 금층에 공석된 $\mathrm{TiO}_{2}$ 부피분율 및 공석된 $\mathrm{TiO}_{2}$ 입자 의 평균 응집 크기, 즉 입도를 그림 3 에 나타내었 다. 그림 3(a)에서 전류 인가 방식에 대한 도금 속 도를 보면, 펄스 전류 방식으로 인가 했을 때의 도 금 속도가 직류 방식보다 빠른 것을 알 수 있다. 이 는 펄스로 인가한 전류는 전류가 흐르는 상태인 on time과 흐르지 않는 off time으로 나뉘는데, 전류가 흐르지 않는 시간 동안 음극에서 소모된 니켈 이온 의 농도 회복으로 인해, 니켈 이온의 환원 반응이 증가하게 되어 나타나는 현상이다. 한편, 그림 3(b)
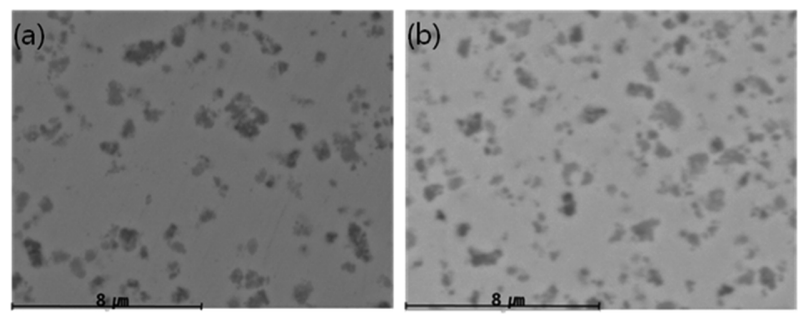

Fig. 4. Cross-sectional images of electrodeposited $\mathrm{Ni}$ $\mathrm{TiO}_{2}$ composite with different current characteristics in the electroplating solution of $\mathrm{pH}$ 1. (a) Duty cycle $50 \%$ (b) D.C.

에 나타낸 니켈 도금층의 $\mathrm{TiO}_{2}$ 부피분율을 보면, 직 류로 인가하여 제조한 니켈 도금층의 $\mathrm{TiO}_{2}$ 부피분 율이 펄스로 제조된 도금층의 $\mathrm{TiO}_{2}$ 의 부피분율보다 높은 것으로 나타났다. 만약, 니켈 도금층에 공석되 는 $\mathrm{TiO}_{2}$ 부피분율이 $\mathrm{TiO}_{2}$ 의 제타포텐셜에 의존한다 면, 분명히 전류를 펄스로 인가하였을 경우가 더 높 게 나와야 한다. 그러나, 실험결과는 직류로 인가했 을 때 $\mathrm{TiO}_{2}$ 의 부피분율이 높았으므로, 3.1절에서 설 명한 것과 같이 $\mathrm{TiO}_{2}$ 의 공석량은 제타포텐셜에 대 한 의존성보다는 증착(도금)속도에 대한 의존성이 크다는 것을 나타낸다. 즉, 상대적으로 빠른 도금층 성장 속도로 인해 도금층 성장면 부근에 존재하는 $\mathrm{TiO}_{2}$ 입자들의 흡착속도가 일정하다고 한다면, 결 과적으로 도금층 부피당 $\mathrm{TiO}_{2}$ 입자 농도가 줄어, 도 금층내의 $\mathrm{TiO}_{2}$ 부피분율이 감소하기 때문이다. 공 석된 $\mathrm{TiO}_{2}$ 입자의 응집 크기 또한 3.1절에서 언급 한 것과 같이 그림 $3(\mathrm{c})$ 에서 보는 것처럼 $\mathrm{TiO}_{2}$ 의 부 피분율이 높은 도금층에서 크게 측정되었다. 그림 4 에는 절단된 시편을 $\mathrm{SEM}$ 으로 관찰한 사진으로 직 류로 전류를 인가한 도금층의 $\mathrm{TiO}_{2}$ 산화물이 더 많이 공석된 것을 볼 수 있으며, 입자의 응집(agglomeration) 이 더욱 심하게 일어난 것을 볼 수 있다. 이러한 입 자들의 응집 작용 또한 직류전류로 도금한 니켈 도 금층의 $\mathrm{TiO}_{2}$ 산화물이 응집된 크기가 크게 나타나 게 하는데 영향을 준 것으로 풀이된다.

\section{3 교반 시간과 방식에 따른 부피분율과 도금속도}

교반은 산화물을 도금 용액에 균일하게 분산시키 며, 금속-산화물 복합 도금층의 형성 기구에서 용 액에 존재하는 산화물을 전극 근처로 이동시켜 공 석이 증가하게 하는 중요한 요소이다 ${ }^{25,26)}$. 전기 도 금에서 산화물 등의 불용성 입자를 교반시키는 방 식은 공기를 도금욕조에 불어넣거나(공기교반), 교 반기 또는 막대 자석을 이용한 기계적 교반(자석교 반), 용액을 펌프로 순환시키는 순환교반 등이 있 으며, 교반 방식에 따른 도금층의 산화물 공석량과 

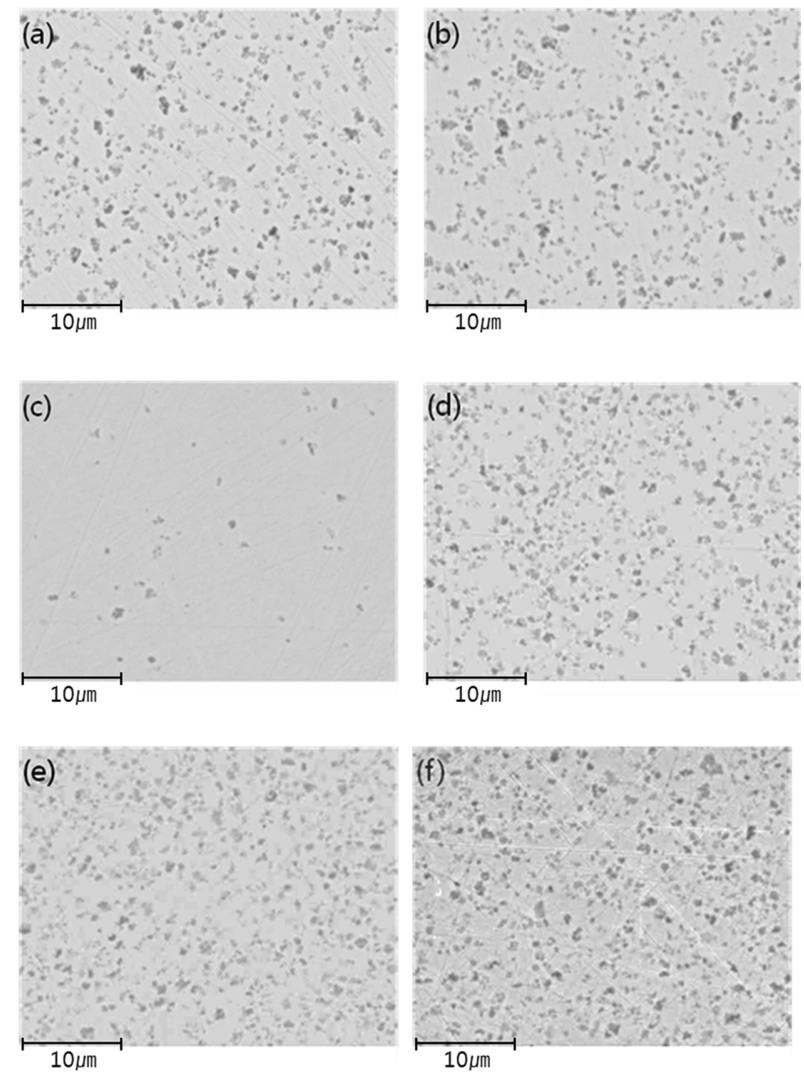

Fig. 5. Cross-sectional images of electrodeposited $\mathrm{Ni}$ $\mathrm{TiO}_{2}$ composite as a function of agitation time by air agitation for (a) $30 \mathrm{~min}$. (b) $24 \mathrm{hrs}$ and (c) $48 \mathrm{hrs}$, and by magnetic bar agitation for (d) 30 min. (e) 24 hrs (f) 48 hrs.

분포는 상이한 것으로 알려져 있다 ${ }^{27)}$. 이에 $\mathrm{Ni}-\mathrm{TiO}_{2}$ 전기도금층에 있어서, $\mathrm{TiO}_{2}$ 의 부피분율과 분산상태 에 미치는 교반의 효과를 알아보기 위하여, 교반 방 식을 조절하고(공기, 자석교반), 교반 시간을 30 분 에서 48시간까지 조절하여 시편을 제조하였다.

이렇게 제조한 시편의 절단면을 주사전자현미경 으로 관찰하여 그림 5 에 나타냈다. 절단면에서 기 공, 크랙 등의 비 산화물과 $\mathrm{TiO}_{2}$ 입자를 구분하기 위해 backscattering으로 시편을 촬영하였으며, 관찰 한 이미지를 분석하여 도금두께로부터 도금속도와 도금층 내에 분포하는 $\mathrm{TiO}_{2}$ 의 부피분율 및 공석된 입자의 응집 크기를 측정하여 그림 6 에 나타냈다. 그림 6(a)에서 보면, 교반방식과 교반시간에 따라 도금속도가 변하는 것을 볼 수 있는데, 특히 공기 교반의 경우에 더 크게 변하였다. 공기교반에서 24시간 교반한 경우의 도금속도를 제외하고는 대 체로 교반시간이 증가함에 따라 도금속도가 증가하 는 것으로 나타났으며, 두 교반방식에서는 자석교 반의 경우보다 공기교반에서 더 높은 도금속도를 보이고 있다. 그 이유는 교반속도의 차이에서 비롯
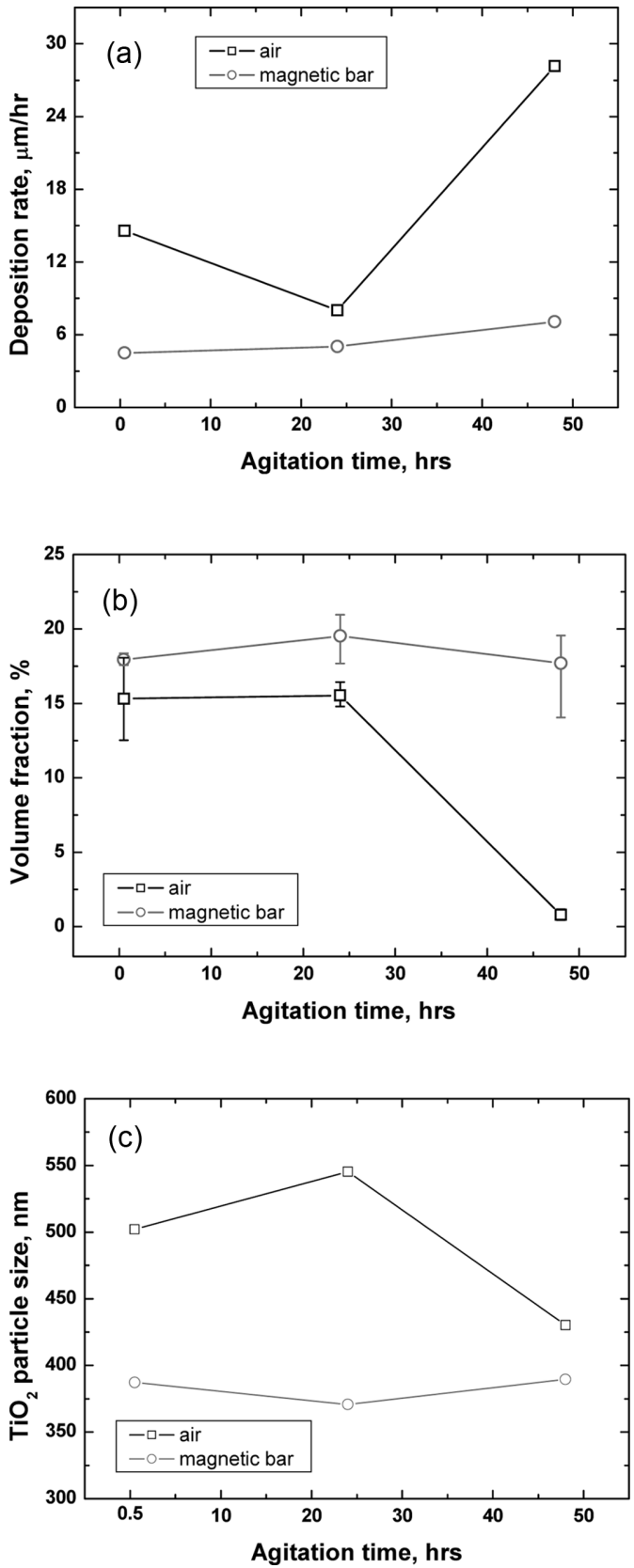

Fig. 6. Electrodeposited $\mathrm{Ni}-\mathrm{TiO}_{2}$ composite as a function of agitation time (a) deposition rate (b) Volume fraction of $\mathrm{TiO}_{2}$ particles (c) Mean size of agglomerated co-deposited $\mathrm{TiO}_{2}$ particles

된 결과로 해석할 수 있다. 우선, 교반속도에 차이 가 있다면, 산화물 분말이 분산되어 있지 않은 순 수 니켈 도금 용액의 경우에는 교반속도가 높을수 록 전류효율 $(=$ 실제 니켈 도금량/이론 니켈 도금량 $\times 100, \%)$ 은 비슷하거나 약간 증가하게 되지만, 산 화물 분말을 포함하고 있는 용액에서는 교반 속도 가 높을수록 전류효율이 낮게 된다 ${ }^{28)}$. 따라서, 인가 한 자석교반 속도가 공기교반보다 상대적으로 높았 기 때문에 자석교반으로 제조한 시편의 도금속도가 낮은 결과가 나타났다. 이것은 교반속도가 높을수 
록 산화물 입자들이 전극 근처로 이동하는 양이 많 아져, 비전도성인 $\mathrm{TiO}_{2}$ 입자들로 인해 니켈 이온의 환원 반응을 방해하게 되어 도금속도를 감소시킨 것으로 생각된다 ${ }^{28)}$. 반면에 전극 근처에서 높은 농 도의 $\mathrm{TiO}_{2}$ 입자가 존재하면, 공석되는 $\mathrm{TiO}_{2}$ 양이 증 가할 것으로 예상되는데, 그림 6(b)의 결과에서 보 듯, 자석교반의 공석량이 공기교반보다 많게 측정 되었다. 한편, 그림 $6(\mathrm{~b})$ 에서 보는 것처럼, 공기교반 의 경우에는 교반 시간이 지날수록 $\mathrm{TiO}_{2}$ 의 부피분 율이 크게 감소하였으나, 자석교반의 경우에는 큰 차이를 보이지 않고 있다. 이것은 공기교반의 경우 교반 시간이 길어질수록 교반이 되지 않는 도금욕 조 사각지대에 $\mathrm{TiO}_{2}$ 입자들이 가라앉아 도금용액 중에 $\mathrm{TiO}_{2}$ 의 농도가 시간이 지날수록 감소하기 때 문으로 보이며, 자석교반의 경우에는 막대자석이 도 금욕조 바닥에서 회전하며 교반하기 때문에 사각지 대가 없어, 도금용액에 존재하는 $\mathrm{TiO}_{2}$ 의 농도가 시 간이 지나도 변하지 않기 때문으로 보인다. 그림 6(c)에 나타낸 교반시간에 따른 공석된 $\mathrm{TiO}_{2}$ 의 응 집 크기는 앞에서의 $\mathrm{pH}$, 전류 인가 방식의 차이에 서와 마찬가지로 공석된 $\mathrm{TiO}_{2}$ 의 부피분율이 클수록 증가하였다. 그러나, 교반 방식으로 비교하면, 자석 교반의 $\mathrm{TiO}_{2}$ 부피분율이 공기교반의 부피분율보다 다소 높았음에도 불구하고, 자석교반의 공석된 입 자의 응집 크기가 더 작았다. 이는 자석교반 방식 을 이용했을 경우, 입자들의 분산 효과 및 비응집 (de-agglomeration) 효과가 공기교반 보다 더 좋았기 때문이라고 판단된다.

이 결과에서 보면 도금속도는 느리지만 도금층 내에 공석된 $\mathrm{TiO}_{2}$ 의 부피분율을 증가시키고, 더욱 미세한 분말입자를 공석하게 하기 위해서는 공기교 반보다는 자석교반이 더욱 효과적임을 알 수 있다.

\subsection{DMAB 첨가와 부피분율, 도금속도}

용액 중에 존재하는 산화물들은 표면에너지를 낮 추기 위해 서로 응집하려는 경향이 있다. 이러한 응 집현상은 표면에너지와 이온세기가 높은 도금용액 에서 매우 심하게 일어나며 ${ }^{29-32)}$, 표면 단면적이 큰 나노크기의 미세한 산화물을 도금층에 공석시키기 어렵게 하는 원인 중 하나이다. 산화물의 응집을 막 는 것은 크게 2 가지로 나뉘어 지는데, 초음파, 볼 밀 등을 이용한 물리적 방법과 계면활성제 등을 이 용하여, 산화물 표면에 이온을 흡착시키고 쿨롱 힘 을 증가시켜 분산 안정성을 유지시키는 화학적 방 법이 있다. $\mathrm{DMAB}$ 는 전해도금에서는 붕소의 공급 원으로서, 무전해 도금에서는 환원제로 쓰이고 있 고 $^{33,34)}$, 계면활성제로 쓰이지는 않으나, 아민그룹을
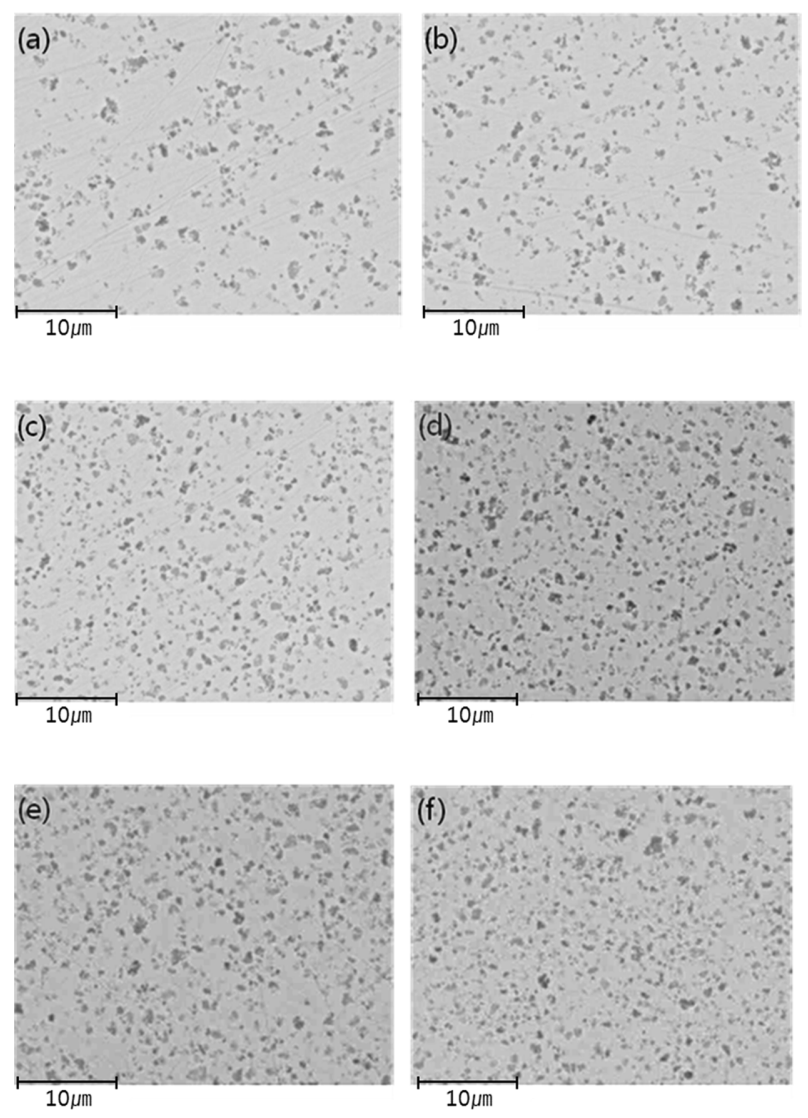

Fig. 7. Cross-sectional images of electrodeposited Ni$\mathrm{TiO}_{2}$ composite with $0.01 \mathrm{M}$ DMAB as a function of agitation time by air agitation for (a) $30 \mathrm{~min}$. (b) $24 \mathrm{hrs}$ and (c) $48 \mathrm{hrs,} \mathrm{by} \mathrm{magnetic} \mathrm{bar}$ agitation for (d) $30 \mathrm{~min}$. (e) $24 \mathrm{hrs}$ (f) $48 \mathrm{hrs}$.

포함하고 있어 ${ }^{18,35)}$, 산화물 분말의 흡착 및 분산 안 정화에 기여할 수 있는 물질로 기대된다.

이에 $0.01 \mathrm{M}$ 농도의 $\mathrm{DMAB}$ 를 $\mathrm{pH}=1.0$ 도금용액 에 첨가하여 $\mathrm{Ni}^{-\mathrm{TiO}_{2}}$ 도금층을 제조하고, 도금시편 을 절단하여, 절단면의 이미지를 그림 7에 나타내 었다. 이에 대하여 도금두께로부터 도금속도와 이 미지 분석 프로그램을 이용한 공석된 $\mathrm{TiO}_{2}$ 의 부피 분율을 계산하여 그림 8 에 나타냈다. 이 그림에서 보면 우선 $0.01 \mathrm{M} \mathrm{DMAB}$ 를 첨가한 용액에서도 두 가지 다른 교반방식에 따른 도금속도, 부피분율 및 입자의 응집 크기의 경향이 앞의 3.3절에서 보인 결과와 유사한 경향을 보이고 있음을 알 수 있다. $\mathrm{DMAB}$ 를 첨가한 용액에서의 도금속도가 공기교반 에서 $\mathrm{DMAB}$ 를 첨가하지 않은 용액(그림 6(a))에서 보다 감소하였으나 자석교반에서는 반대로 약간 증 가하고 있다. 이것은 $\mathrm{DMAB}$ 가 전극과 산화물 주위 에 흡착하여 니켈 환원 반응을 방해하여 생긴 결과 로 생각된다. 교반 속도가 상대적으로 빠른 자석교 반의 경우에는 약간 증가했으나, 차이가 크지 않아 오차 범위에 속하는 것으로 보인다. 이에 따른 도 
금층 내에 공석된 $\mathrm{TiO}_{2}$ 의 부피분율(그림 $8(\mathrm{~b})$ )은 $\mathrm{DMAB}$ 를 첨가한 경우 두 교반 모두 교반시간이 증 가하면 증가하는 경향을 보이고 있으나 그 양은 크 지 않음을 알 수 있다. 이것은 $\mathrm{DMAB}$ 를 첨가하고 교반을 하는 경우, $\mathrm{DMAB}$ 가 $\mathrm{TiO}_{2}$ 주위에 흡착하여 분산안정성을 증가시키기 때문으로 생각되나, 그 효 과는 크지 않아 나타나는 현상으로 보인다. 한편 그 림 $8(\mathrm{c})$ 에 나타낸 것처럼, $\mathrm{DMAB}$ 첨가에 따른 도 금층 내에 공석된 $\mathrm{TiO}_{2}$ 응집 크기도 $\mathrm{DMAB}$ 첨가 유무에 관계없이 큰 변화가 없었다.
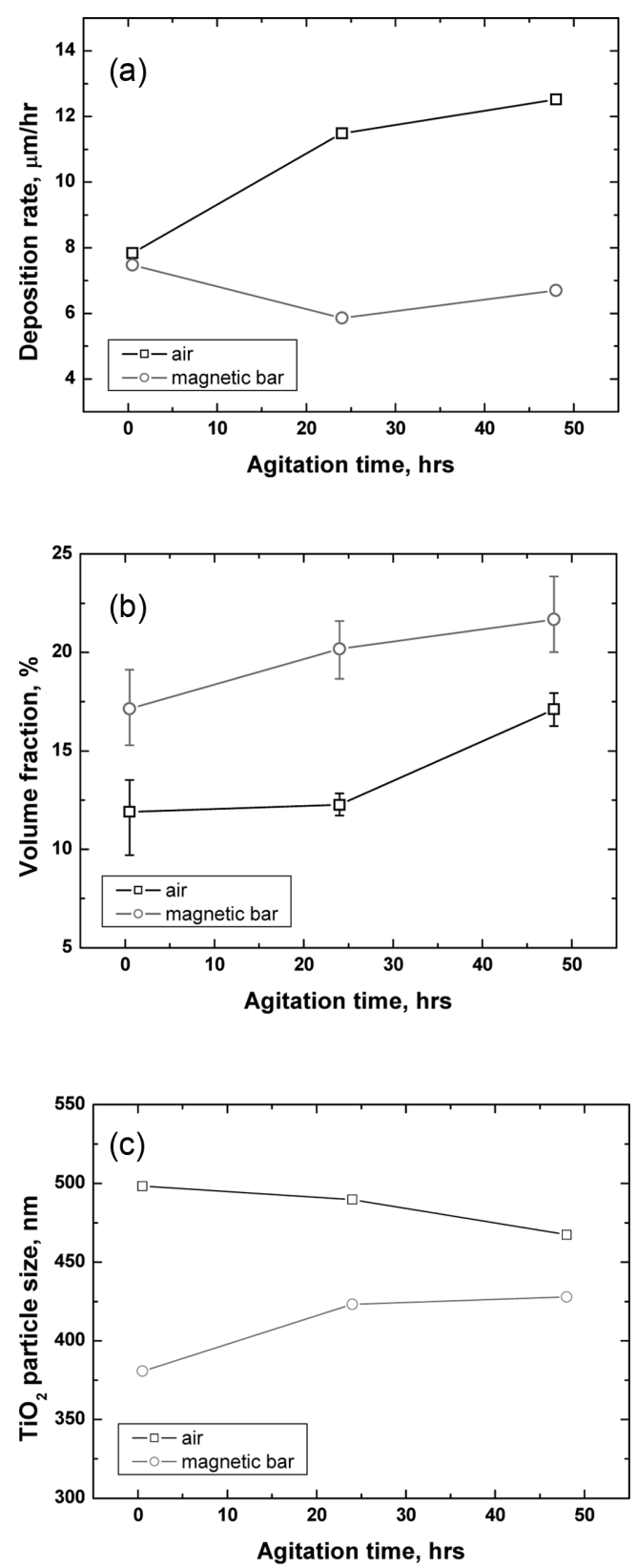

Fig. 8. Electrodeposited $\mathrm{Ni}-\mathrm{TiO}_{2}$ composite with $0.01 \mathrm{M}$ DMAB as a function of agitation time (a) deposition rate (b) Volume fraction of $\mathrm{TiO}_{2}$ particles (c) Mean size of agglomerated codeposited $\mathrm{TiO}_{2}$ particles

\section{5 도금조건 변화에 따른 복합도금층의 열적 안정성}

$\mathrm{pH}$ 1 3.4 범위에서 제조한 시편과 직류, 펄스 전 류로 제조한 시편을 대상으로 $200,400,600,800^{\circ} \mathrm{C}$, 2시간동안 열처리를 한 후, 경도를 측정하여 열적 안정성을 평가하고, 이를 그림 9(a)에 나타냈다. 이 그래프에서 보면, 상온에서 측정한 경도값은 $\mathrm{pH}$ 가 증가하면 증가하는 경향을 보이는데, 이것은 $\mathrm{Ni}$ 도 금층 내에 공석된 $\mathrm{TiO}_{2}$ 의 부피분율의 증가(그림 2(a))와는 반대되는 것으로 나타났다. 하지만, 열처 리 온도가 $200^{\circ} \mathrm{C}$ 이상이면, 그 순서가 역전되고 있
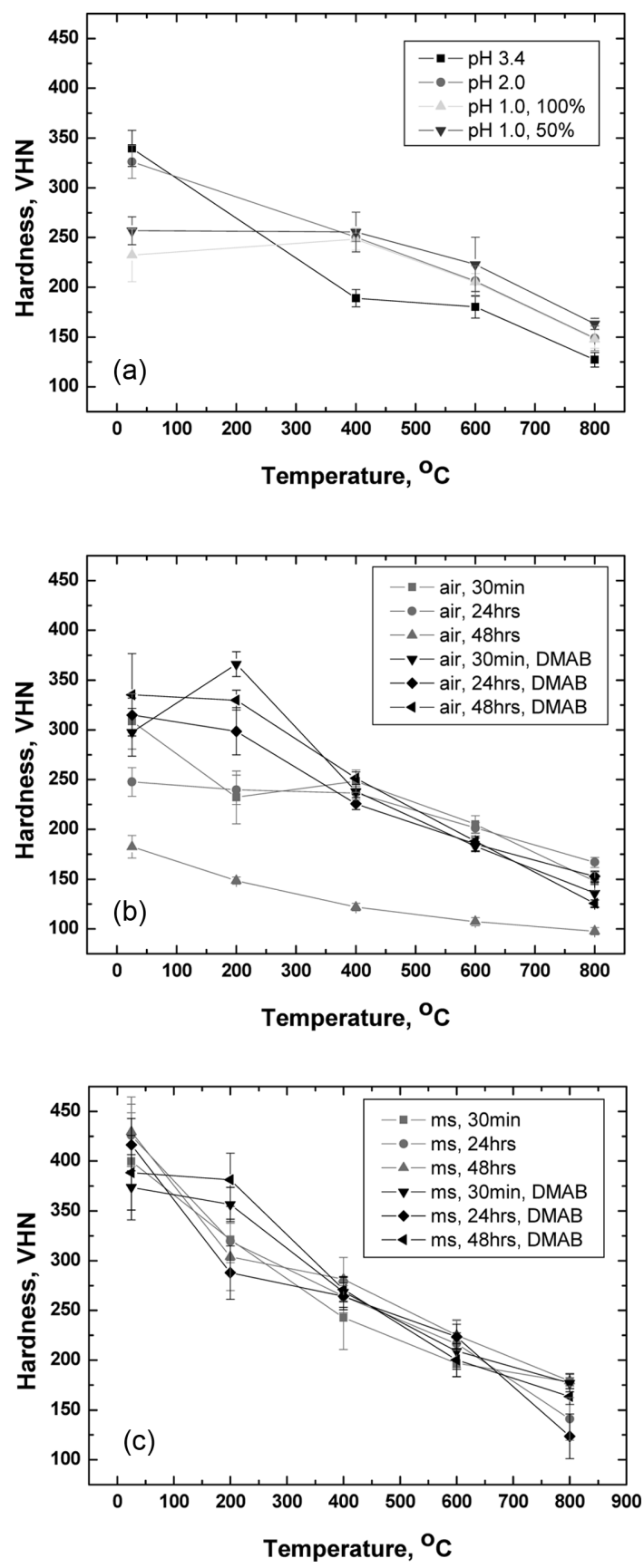

Fig. 9. Vickers hardness values with different electroplating parameters. (a) pH, current characteristics (b) Air bubble agitation (c) magnetic stirrer agitation 
는데, 일반적으로 복합도금층의 경도는 공석된 산 화물의 부피분율이 증가하면 증가한다, ${ }^{5,10,15,36)}$. 이러 한 특이한 현상은 $\mathrm{pH}$ 가 높을수록 전류효율이 증가 하면서 결정립 크기가 작아지면서, 도금 속도가 증 가하여 잔류응력이 회복될 시간적 여유가 없고, 또 한 불순물 $\left(\mathrm{H}_{2}, \mathrm{~S}\right.$ 등)의 침입 등이 증가하여 도금층 의 잔류응력이 증가한 것으로 생각된다 ${ }^{37}$. 따라서, 잔류 응력에 대한 경도의 증가는 $200^{\circ} \mathrm{C}$ 이상에서 열처리 할 경우, 잔류 응력이 제거되면 없어질 것 이고, $\mathrm{TiO}_{2}$ 공석에 따른 분산강화 효과로 인해 $\mathrm{TiO}_{2}$ 부피분율이 높은 시편의 경도 감소가 더 적을 것이 다. 즉, $\mathrm{pH} 3.4$ 보다는 1,2 에서 만든 시편에 $\mathrm{TiO}_{2}$ 가 더 많이 공석 되었기 때문에 열처리를 하여 잔 류응력이 제거되고, $\mathrm{TiO}_{2}$ 가 더 많이 공석된 시편의 결정립 성장 억제 효과로 인해 경도가 역전되어 나 타난 것이다. 전류 인가 방식을 달리하여 제조한 경 우에는 펄스 전류를 인가하여 제조한 시편의 경우 와 직류 전류로 인가하여 제조한 시편의 $\mathrm{TiO}_{2}$ 의 부 피분율의 차이가 크지 않아, 열처리 온도에 따른 경 도값의 차이가 크지 않은 것으로 나타났다.

또한, 공기교반과 자석교반, $\mathrm{DMAB}$ 첨가한 시편 을 대상으로 $200,400,600,800^{\circ} \mathrm{C}$ 온도에서, 2 시간 동안 열처리를 한 후에 경도를 측정하여 각 시편의 열적안정성을 측정하여 그림 9(b) 및 (c)에 나타내 었다. 이 그림에서 보면, 공기교반으로 만든 시편의 경도보다 자석교반으로 만든 시편의 경도가 높게 나타났는데, 이것은 자석교반 조건에서 공석된 $\mathrm{TiO}_{2}$ 의 함량이 공기교반에서 얻은 시편보다 높았기 때 문이다. 한편, $0.01 \mathrm{M}$ 농도의 $\mathrm{DMAB}$ 를 첨가한 시 편의 경우, 상온에서 공기로 교반하고 $\mathrm{DMAB}$ 를 첨 가하지 않은 시편보다 경도가 약간 높게 나타났는 데, 이것은 $\mathrm{DMAB}$ 첨가로 인하여 도금층에 형성되 는 잔류응력의 영향으로 생각된다 ${ }^{38)}$. 그러나 자석 교반의 경우에는 $\mathrm{DMAB}$ 첨가 유무에 상관없이 경 도가 유사하게 나타났는데, 이것은 자석교반으로 얻 은 도금층에 함유된 $\mathrm{TiO}_{2}$ 의 부피분율이 높기 때문 에 $\mathrm{DMAB}$ 첨가로 약간 증가하는 도금층 자체의 잔 류응력이 큰 영향을 미치지 못했기 때문으로 사료 된다.

\section{4. 결 론}

$\mathrm{Ni}-\mathrm{TiO}_{2}$ 전기 도금 층의 형성에서 $\mathrm{pH}$, 전류 인가 방식, 교반 방식과 시간, $\mathrm{DMAB}$ 첨가가 도금층에 미치는 영향을 조사하여 다음과 같은 결론을 얻었다.

1. $\mathrm{pH}$ 가 감소할수록 $\mathrm{Ni-TiO}$ 복합 전기도금층의 도금속도는 감소하였으며, 공석된 $\mathrm{TiO}_{2}$ 부피분율과
입자의 응집 크기는 증가하였다.

2. 전류 인가 방식에 있어서, 펄스 전류보다 직류 를 인가했을 때 $\mathrm{Ni}_{-} \mathrm{TiO}_{2}$ 복합 전기도금층의 도금속 도는 감소하였으며, 공석된 $\mathrm{TiO}_{2}$ 부피분율과 입자 의 응집 크기는 증가하였다.

3. 공기교반을 한 경우, 교반시간이 길어지면 전 기도금층의 도금속도는 대체로 증가하였으며, 공석 된 $\mathrm{TiO}_{2}$ 부피분율과 입자의 응집 크기는 감소하였 다. 반면, 자석교반의 경우에는 교반시간과 $\mathrm{TiO}_{2}$ 공 석량, 응집 크기 및 도금속도에 큰 차이가 없었다.

4. 공기교반을 한 경우보다 자석교반을 한 경우, $\mathrm{Ni}-\mathrm{TiO}_{2}$ 복합 전기도금층의 도금속도는 감소하였으 나, 공석된 $\mathrm{TiO}_{2}$ 부피분율은 증가하였고, 입자의 응 집 크기는 감소하였다.

5. 0.01 M DMAB를 도금용액에 첨가하면, 공기교 반의 경우, $\mathrm{DMAB}$ 를 첨가하지 않은 경우와 비교하 여 도금속도는 약간 감소하였으나, 전기도금층에 공 석된 $\mathrm{TiO}_{2}$ 부피분율, 및 입자의 응집 크기에는 큰 영향이 없었다. 반면, 자석교반의 경우에는 이 모든 것에 큰 차이가 없었다.

6. 교반방식에 따른 복합도금층의 경도는 자석교 반을 한 경우가 공기교반을 것보다 높았다.

7. 열적 안정성의 경우, $200 \sim 800^{\circ} \mathrm{C}$ 범위에서 열처 리를 한 경우, $\mathrm{pH}$ 가 낮을수록 $\mathrm{Ni}^{-\mathrm{TiO}_{2}}$ 복합도금층 의 열적안정성이 우수하였다.

8. 도금층에 공석되는 산화물의 부피분율은 산화 물의 제타포텐셜보다 도금속도에 더 크게 의존하는 것으로 나타났다.

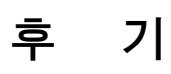

본 연구는 교육과학기술부에서 주관하는 원자력 중장기계획사업의 지원으로 이뤼졌습니다.

\section{참고문헌}

1. P. K. Sinha, N. Dhananjayan, H. K. Chakrabarti, Plating, (1973).

2. E. S. Chen, F. K. Sautter, Plating and Surface Finishing, 28 (1976).

3. J. Zahavi, J. Hazan, Plating and Surface Finishing (1983) 57.

4. K.-N. Sun, X.-N. Hu, J.-H. Zhang, J.-R. Wang, Wear, 196 (1996) 295.

5. C. S. Lin, C. Y. Lee, C. F. Chang, C. H. Chang, Surf. Coat. Technol., 200 (2006) 3690.

6. M. J. Kim, J. S. Kim, D. J. Kim, H. P. Kim, Metals and Mater Int., 15(5) (2009) 789.

7. B. Szczygiel, M. Kolodziej, Electrochimica Acta 
50 (2005) 4188.

8. T. Lampke, A. Leopold, D. Dietrich, G. Alisch, B. Wielage, Surf. Coat. Technol., 201 (2006) 3510.

9. F. K. Sautter, J. Electrochem. Soc., 110(3) (1963) 557

10. G. R. Lakshminarayanan, E. S. Chen, F. K. Sautter, Plating and Surface Finishing, (1976).

11. M. Ghouse, M. Viswanathan, E. G. Ramachandran, Metal Finishing, 31 (1980).

12. A. Moller, H. Hahn, Nanostructured Materials, 12 (1999) 259.

13. C. Kollia, C. Patta, P. Vassiliou, V. Kasselouri, Rev. Metal. Madrid Vol. Extr., (2005) 227.

14. J. L. Stojak, J. Fransaer, J. B. Talbot, Adv. Electrochem. Sci. Eng., 7 (2001) 193.

15. V. O. Nwoko, L. L. Shreir, J. Appl. Electrochem. 3 (1973) 137.

16. C. White, J. Foster, Transactions of the Institute of Metal Finishing, 56 (1978).

17. E. S. Chen, G. R. Lakshminarayanan, F. K. Sautter, Metallurgical Transactions, 2 (1971) 937.

18. T. W. Tomaszewski, L. C. Tomaszewski, H. Brown, Plating, (1969) 1234.

19. C. C. Lee, C. C. Wan, J. Electrochem. Soc., 135(8) (1988) 1930.

20. P.-A. Gay, P. Bercot, J. Pagetti, Surf. Coat. Technol., 140 (2001) 147.

21. M. Kosmulski, J. Colloid. Interface Sci., 298 (2006) 730 .

22. H. Simunkova, P. P. Garcia, J. Wosik, P. Angerer, H. Kronberger, G. E. Nauer, Surf. Coat. Technol., 203 (2009) 1806.

23. M. H. Fawzy, M. M. Ashour, A. E.-H. M. A. El-
Halim, J. Chem. Tech. Biotechno., 66 (1996) 121.

24. J. Foster, B. Cameron, Transactions of the Institute of Metal Finishing, 54 (1976) 178.

25. N. Gulielmi, J. Electrochem. Soc., 119(8) (1972) 1009.

26. J. P. Celis, J. R. Roos, C. Buelens, J. Electrochem. Soc. 134(6) (1987) 1402.

27. P. W. Martin, Grad. Inst. P., Metal Finishing, 11(130) (1965) 409.

28. P. R. Webb, N. L. Robertson, J. Electrochem. Soc., 141(3) (1994) 669.

29. N. S. Qu, K. C. Chan, D. Zhu, Scripta Materialia, 50 (2004) 1131.

30. F. Hou, W. Wang, H. Guo, Appl Surf. Sci., 252 (2006) 3812.

31. D. Lee, Y. X. Gan, X. Chen, J. W. Kysar, Mater. Sci. Eng. A, 447 (2007) 209.

32. M. Kosmulski, J. B. Rosenholm, J. Phys. Chem., 100 (1996) 11681.

33. F. Pearlstein, R. F. Weightman, J. Electrochem. Soc., 121(8) (1974) 1023.

34. L. D. Burke, B. H. Lee, J. Appl. Electrochem., 22 (1992) 48.

35. A. Chiba, H. Haijima, K. Kobayashi, Surf. Coat. Technol., 169-170 (2003) 104.

36. M. N. Joshi, M. Totlani, J. Electrochem. Soc. India, 28(1) (1979) 35.

37. M. H. Seo, D. J. Kim, J. S. Kim, Thin Solid Films, 489 (2005) 122.

37. M. H. Seo, D.-J. Kim, J. S. Kim, Metals and Mater Int., 13(5) (2007) 365. 